\title{
CREEPING CONDITIONALITY IN THE UK: FROM WELFARE RIGHTS TO CONDITIONAL ENTITLEMENTS? ${ }^{1}$
}

\begin{abstract}
A widely recognised central tenet of New Labour's 'Third Way' is no rights without responsibilities. The extent to which this idea underpins the British government's approach to welfare reform has been extensively commented upon. Initially, the article places the UK reforms in the context of wider theoretical debates about welfare reform in Western states. It then highlights the ways in which a principle of conditionality is being practically applied in a wide range of sectors in the UK including; social security, housing, education, and health. The details and impact of recent relevant legislation and initiatives are discussed. It is argued that as policies based on conditional entitlement become central to the ongoing process of welfare reform the very idea of 'welfare rights' is systematically undermined.
\end{abstract}

Key Words: Rights, Responsibilities, Conditionality, Welfare Reform

\footnotetext{
${ }^{1}$ The author would like to thank Malcolm Harrison, Kirk Mann, Simon Prideaux, the journal editors and two anonymous referees for their comments on earlier drafts of this manuscript.
} 


\section{Introduction}

According to Giddens (1998) the prime motto of Third Way politics is no "rights without responsibilities” (:65). Indeed, the extent to which this principle underpins the British Government’s general approach to welfare reform has been extensively commented upon (Deacon, 2002a; Dwyer, 2002, 2000, 1998; Prideaux, 2001; Etzioni, 2000; Lister, 1998; Powell, 1999)². Following this introduction, part one of the paper places the recent UK welfare reforms, which have a 'principle of conditionality' at their core, within a discussion of the wider emergence of 'active/Third Way' social policies in many Western welfare states. Part two then highlights the ways in which conditionality is being practically applied in an increasingly wide range of UK welfare policy areas namely; social security, housing, education, and health. Details of recent, relevant legislation and initiatives in these sectors are discussed. Part three, moves on to explore some of the effects of this approach for welfare provision. It is argued that as policies based on conditional entitlement become central to New Labour's vision the very idea of 'welfare rights' is systematically undermined. The implications of this approach, in terms of New Labour's welfare project and, more generally, citizens' social rights are noted in the conclusion.

\footnotetext{
${ }^{2}$ A discussion of the philosophical underpinnings of New Labour's approach to welfare reform lies beyond the remit of this paper. Interested readers should refer to: Deacon (2002a); Dwyer (2000); Heron and Dwyer (1999): Driver and Martell (1998); Levitas (1998).
} 
Echoing the earlier work of R. Kent Weaver (1986), Pierson argues that "the contemporary politics of the welfare state is the politics of blame avoidance” (1996 :179). Third Way welfare reforms that stress reduced access to public welfare provision, a strong link between rights and responsibilities, and an increasingly moral agenda meet the requirements of cost containing governments rather than the needs of citizens. The welfare rights of those deemed 'irresponsible' because they cannot, or will not, meet certain state endorsed standards or regulations may be withdrawn or reduced. This enables politicians to place the blame for the predicament of those whose right to publicly funded welfare is reduced or removed firmly at the door of the individuals concerned. Their exclusion from public welfare arrangements thus becomes less problematic for the government (Dwyer, 2000, 1998). Inactive welfare recipients thus become expedient ‘scapegoats' (see Weaver, 1986 :387) for administrations looking to avoid the blame for any negative outcomes that may ensue for those citizens whose access to collective social welfare provision is diminished as a consequence of the introduction of active/Third Way welfare policies.

\section{A shift from 'welfare society' to 'active society'}

Built around three rights elements (i.e. civil, political and social) Marshall’s theory (1950/1992) of citizenship implied an equality of status universally enjoyed by all deemed to be citizens. It was the addition of a third social rights element which promised,

the whole range from the right to a modicum of economic welfare and security, to the right to share to the full in the social heritage and to live civilised life according to the standards prevailing in society” (Marshall, 1992: 8), 
that made the citizenship status of the social democratic post war welfare settlement (PWWS) both distinctive and substantive when compared to that which had gone before. Although Marshall saw citizenship as a status that entailed both rights and duties it is clear that a general concern with social rights, rather than responsibilities characterised his approach. Many (e.g. Etzioni, 2000, 1997; Mead, 1997; Giddens, 1994) have subsequently criticised his account for placing the idea of unconditional entitlement to welfare at the centre of his account. Marshall's view that rights to welfare should be both universal and unconditional was shared by Titmuss, Tawney and others, who were also concerned to ensure that public welfare would lessen inequalities and foster a sense of social solidarity between citizens (Deacon, 2002a; Cox, 1998).

Fifty years on the ideas that were central to these "conceptual architects of the welfare state” (Cox, 1998: 3) are viewed by many to be both outdated and likely to exacerbate passive welfare dependency. In recent years a number of profound economic, political and social changes in Western societies (rf. Williams, 1999; Cox, 1998; Walters, 1997) have resulted in significant changes in the organisation of contemporary welfare states (Taylor-Gooby, 2002). Much talk of a new ‘Third Way’ politics has emerged; most notably but not exclusively in the UK and USA. According to a chief exponent (Giddens, 1998, 1994) the correct role for governments to assume in relation to welfare is to encourage an 'entrepreneurial culture' that rewards 'responsible risk takers'. This new 'social investment state', meets its commitments to social justice and equality via the redistribution of 'possibilities' (primarily the opportunity to work and the right to education), rather than wealth. Giddens is also unequivocal in making a reciprocal relationship between rights and responsibilities central to his approach. 
Embraced with some enthusiasm by New Labour in Britain, (Blair, 1998) this 'new' politics can be seen as a fundamental challenge to the "post war idea of the welfare state based on the principle of universal entitlement derived from citizenship” (Cox, 1998: 3).

Whilst many governments optimistically endorse welfare which prioritises responsible individual agency as a panacea for dependency, others are more sceptical about the current direction of welfare reform. Walters (1997) argues that the 'welfare society' of the past that promised, theoretically at least, a common citizenship status which guaranteed a universal minimum of welfare rights, has today been superseded by the 'active society' in which increasingly individuals can only access social rights if they are willing to become workers in the paid labour market (PLM). Walters is aware of the false universalism of the PWWS and the fact that that a person's participation and position in the highly stratified PLM has long been of central importance in defining the quality and extent of an their access to public provision. His key point is that a fundamental shift has occurred. Although imperfect, in the 'welfare society' of the past the state exempted certain 'inactive' groups from PLM participation. This was because either they were recognised as making socially valid contributions elsewhere (e.g. women engaged in informal/familial care work) or because they had previously contributed (e.g. retired senior citizens). Today, "many of these assumptions about the specifically social obligations and consequent rights of the citizen no longer apply... The active society makes us all workers” (Walters, 1997: 223-4). Policies that seek to promote unconditional entitlement to public welfare benefits are seen as entrenching welfare dependency. If necessary, reluctant individuals should be forced into activity by the application of benefit sanctions. Only 
those who 'take charge' of their own lives are deemed to be responsible 'active' citizens (Wetherly, 2001). This is certainly an agenda that New Labour have been keen to endorse and such ideas enjoy more extensive support. Increasingly they inform policy across Europe (Lǿdemel and Trickey, 2000; Van Oorschot, 2000), in the USA (Deacon, 2002a; Prideaux, 2001; O’Connor, 1998), Australia and elsewhere (Goodin, 2002).

In the USA influential thinkers like Lawrence Mead $(1997,1986)$ have long argued that the existence of unconditional social benefits has helped to create a welfare dependant 'underclass'. The welfare state of the past offered support but expected little in return. Mead (1997) argues that not only is conditionality both generally popular and functional but also that the imposition of compulsory work conditions for the recipients of state benefit effectively re-establishes their right to be regarded as citizens. He believes that previously permissive welfare regimes and the unconditional nature of their benefits marked out the poor as recipients of state charity rather than as citizens entitled to state support in return for their acceptance of specified responsibilities. Conditionality thus restores their right to equal citizenship status because, as Mead has stated, “only those who bear obligations can truly appropriate their rights” (1986: 257). A case for recipients of social welfare to voluntarily accept their obligations could of course be made, but Mead has rejected this as unlikely to succeed. He holds that it is right and proper for the state to use paternalistic authority to compel individuals to return to the labour market.

These type of ideas have found practical expression in the reform of the US welfare system in the past decade. 'Workfare' schemes in which state welfare benefits are 
dependant on recipients accepting attendant state-defined work are now a central feature of social policy in the USA (King, 1999). The Personal Responsibility and Work Opportunity Reconciliation Act (1996), which sets a five year lifetime limit for the receipt of benefits and enforces more stringent work requirements on lone mothers illustrates the extent to which limited and conditional welfare benefits have become the accepted norm in the USA (rf Deacon, 2002a; Béland et al, 2001 for details). This shift towards social policies that combine coercive paternalism and conditional entitlement to effectively reduce the rights of vulnerable citizens is not without its opponents (see King, 1999). In the context of this paper, however, it is important to note that American ideas and experiences have influenced UK reform process and New Labour appears to be unwilling to listen to such critics.

The consequences of such reforms should not be dismissed lightly. Pierson (2001; 1996) has argued that mature welfare states are resilient institutions which are often resistant to retrenchment. The new politics of welfare is different from the earlier politics of expansion. Retrenchment is generally unpopular and politicians who attempt to cut back public welfare are in the business of blame avoidance rather than credit claiming. They also often face entrenched opposition from voters and interest groups. Pierson states that measuring retrenchment is a difficult task. One significant indicator of a structural shift in welfare states are "dramatic changes in benefit and eligibility rules that signal a qualitative reform of a particular program” (1996 :157). The welfare reform policies outlined below illustrate that such a qualitative shift is ongoing within the UK welfare state. The idea of welfare rights is being superseded by one of conditional entitlement. The change is not limited to Britain. As Deacon (2002a) notes ending the right to welfare was central to US welfare reform in the 
1990s. It is possible to dismiss the UK reforms and policy changes in the outlined below as minor and of little long-term consequence but as Cox notes such 'tinkering' often has far reaching consequences.

Though tinkering is often viewed as a substitute for real reform it can lead to important change especially when its cumulative impact is taken into consideration. Years of austerity measures, numerous small manipulations in programme eligibility, decentralisation of administrative responsibility, a shift from passive to active unemployment measures, all of these are important changes (1998:2).

\section{Creeping conditionality in the UK}

A principle of conditionality holds that eligibility to certain basic, publicly provided, welfare entitlements should be dependent on an individual first agreeing to meet particular compulsory duties or patterns of behaviour (Deacon, 1994). This section aims to map the extent to which this principle now informs welfare policy in the UK. Very few, if any, welfare rights are totally unconditional. In many ways, a significant number of social rights are and always have been, to some extent conditional. Principles of (contingent) universality, contribution and social assistance have long been a feature of most European welfare states. It has also recently been argued that conditionality features throughout the history of British welfare (Powell, 2002). The vital point to note here, however, is the extent to which a principle of conditionality has become central to the organisation of contemporary public welfare in the UK. As Deacon (2002a) notes, the whole hearted endorsement of this approach by a British 
Labour government would have been unthinkable less than a decade ago, but it is now fundamental to their vision of a $21^{\text {st }}$ century welfare state.

\section{Social Security}

A principle of conditionality is at the core of New Labour's welfare to work agenda. In April 2002 when launching the national Job Centre Plus initiative the Prime Minister restated the major themes central to his government's welfare reforms. Emphasising an enabling welfare state, he stressed three elements in the government's strategy for reducing dependency on social welfare benefits.

The first is Job Centre Plus; the second to extend the concept of the New Deals and rights and responsibilities beyond the unemployed to the sick and disabled (sic). The third part is new opportunities for skilled jobs (Blair, 2002: 6).

Job Centre Plus retains many of the central components of the 'One' initiative that it replaced. Anyone claiming working age benefits must agree to take part in a work focused interview with an assigned adviser as a condition of benefit eligibility. The list of benefits that this measure covers is extensive and includes; jobseeker's allowance, income support, incapacity benefit, maternity allowance, bereavement benefits, industrial injuries disablement benefit, care allowance and the social fund (Treolar, 2001).

Within the existing 'New Deals' for the young and long-term unemployed the link between rights and responsibilities has been clearly defined since 1997. Failure to take up one of the four work/training options offered results in punitive benefit sanctions. Claimants can lose some or all of their benefit for a period of between 2 and 26 weeks 
depending on circumstances (DWP, 2002a). Detailed data on the numbers effected by cuts and suspensions in various benefits are hard to attain but in the quarter yearly periods between October/December 1998 and July/September 2000 the numbers of young people sanctioned varied between a low 2,695 and a high of 5,157 (Bivand, 2001). Government figures relating to JSA show some 21,000 claimants as subject to sanctions in May 2002 (DWP, 2002a).

Various similar, although perhaps less severe approaches, for lone parents and disabled people are clearly part of the immediate future. Entitlement conditions for both groups are becoming more restrictive. From April 2001 work focused interviews became compulsory for most lone parents claiming income support with children aged 13 years plus. ${ }^{3}$ Since April 2003 all lone parents claiming income support have been required to attend. Coupled to this benefit entitlement for many lone parents is conditional on a woman naming a child's absent father under rules introduced under the Child Support Act 1991.

In relation to disabled people reforms introduced in the Welfare Reform and Pensions Act (1999) - strengthening the link between work and entitlement to incapacity benefit so that only those who have recently been in work and paid NI contributions are eligible; the application of the 'all work test' (now called the capability assessment); attendance at a work focused interview - can be seen as meeting the requirements of a cost cutting government rather than meeting the needs of disabled people who do not work. The Prime Minister is keen to emphasise that the

\footnotetext{
${ }^{3}$ In the period between $30^{\text {th }}$ April 2001 and $29^{\text {th }}$ March 2002 1,531 lone parents were sanctioned for failing to attend the compulsory interview without good cause (Hansard, 2002).
} 
government's social security strategy is focused on enabling (re)entry into the PLM whilst simultaneously recognising the needs of those who are unable to work because of personal impairments The stated aim of present policy is to return as many of the 2.7 million people currently in receipt of disability and incapacity benefits to the workforce (Blair, 2002).

The third element of the UK government's strategy, the creation of opportunities for real skilled jobs, establishes the limits of New Labour's, rather than claimants, responsibilities. The idea behind the ‘Ambitions' programmes announced as part of Job Centre Plus is to enable people to get higher skilled, better paid jobs and so tackle a situation where people remain unemployed when certain employers can't get skilled staff (Blair, 2002). Such job creation initiatives should be broadly welcomed but allied to this, as Treolar notes, creeping conditionality is becoming an established part of government benefit policy

For more and more claimants, benefit entitlement is going to be dependent on satisfying work related conditions. Where that leaves the concept of a right to benefit is a matter for speculation. The impact on claimant attitude and behaviour is yet to become fully apparent (2001 :3)

Alongside the enforcement of work related conditions, the linking of certain benefit rights to behavioural conditions is also an increasing aspect of UK social policy debates. Following Frank Field (Minister for Welfare Reform 1997-1998), the government strongly supported the proposals outlined in his Housing Benefit (Withholding of Payment) Bill (2002). This proposes that the right to housing benefit be withdrawn, for a maximum of 12 months, from individuals who (or whose 
children) have been convicted twice, within a three year period, by the courts of antisocial behaviour. Field is explicit that his aim is to reform the behaviour of a small minority of persistent offenders. He believes that in extreme circumstances children should be taken into care until their parents either agree to control them adequately or start to behave in an appropriate manner themselves (Field, 2002). Most recently, (January 2004), the Government has announced that it will no longer be supporting the Bill, however, the relevant Minister noted, "we want to judge the effectiveness of the range of existing measures before introducing a new one. But we have not ruled out other means, in the future as we learn from experience and establish what works” (Pond, in DWP, 2004).

The most controversial, suggestions to emerge were those which proposed withdrawing of Child Benefit from parents whose children persistently truant from school and/or engage in anti-social behaviour (Finch, 2002). Following strong dissent from both within and beyond the government the suggestions have since been dropped. The initial enthusiasm with which the Prime Minister and many of his inner circle embraced this and the housing benefit proposals does, however, illustrate both the ideological distance that New Labour has travelled in a relatively short time and the extent to which a principle of conditionality now informs much social security policy.

\section{Housing}

Aside from the new developments in relation to Housing Benefit discussed above conditionality is now a key feature of contemporary social housing policy in the UK. 
Arguably, against a political backdrop which increasingly identifies certain social housing tenants as part of an 'underclass', a more punitive approach to the management of social housing has emerged. Linking housing rights to responsible behaviour is not, however, straightforward. Definitions of anti-social behaviour may encompass a wide range of conduct, from children playing where they annoy neighbours, to serious criminal activity, racial harassment or violent attacks (Flint, 2002; Card, 2001; Hunter 2001).

The Housing Act (1996) delivered by the last Conservative administration bought about significant changes that linked the right to reside in social housing to specific behavioural responsibilities. Probationary tenancy periods (PTPs) of twelve months duration were introduced. These render tenants who behave in an 'anti-social' manner within the trial period liable to eviction and are local authorities can revoke the right to a future secure tenancy. It also became easier for social and private landlords to evict existing tenants on the grounds of anti-social behaviour. As Hunter argues, The approach of the 1996 Act can be said to be one which targets those living in social housing, reduces and limits the rights of such people, and ultimately takes away the one of their most basic rights, the right to live in their home (2001: 228).

A range of instruments are now available to social landlords to manage tenants which make the right to housing subject to conditionality. They appear to be having a practical effect. By 1999 30\% of local authorities (LAs) and 13\% of registered social landlords (RSLs) had introduced PTPs. Half of these local authorities had evicted tenants in a 12 month period with 19\% of evictions based on nuisance (Nixon et al, 1999 cited in Card, 2001). Evidence also suggests that housing agencies are managing 
anti-social behaviour by encouraging tenants to be responsible e.g. by introducing Good Neighbour Charters in Glasgow ${ }^{4}$ ) and by allowing representatives to sit on letting committees to vet potential tenants (Flint, 2002). The exclusion of nuisance neighbours via the denial of a tenancy is now an established part of local policy. Figures from Smith et al (2001), note that “47.7\% [of LAs and RSLs surveyed] excluded on the basis of ex-tenant behaviour and 40\% for tenant behaviour” (cited in Card, 2001 :210). A consultation paper indicates that the government is in favour of strengthening and expanding the powers of social landlords in order to 'crack down' on anti-social tenants (DTLR, 2002).

New Labour have also introduced anti-social behaviour orders (ASBOs) in the Crime and Disorder Act (1998). These civil court orders grant a LA or the police the power to prohibit an individual from acting in a specified anti-social manner and/or the power to exclude an individual from their home or other specified locality. It is, however, a criminal offence (potentially punishable by imprisonment) to break the conditions set out in an order. In the period $1^{\text {st }}$ April 1999 to 30 ${ }^{\text {th }}$ June 20031337 ASBOs were served (Home Office, 2003a). ASBOs have been used successfully in neighbourhood disputes and to tackle youth crime and are now beginning to be used to remove people from a particular area in order to combat street crimes such as drug dealing and prostitution. The government is convinced of the value of ASBOs and is committed to extending their scope and use in new legislation (Home Office, 2003b).

In general the courts have been supportive of social landlords and LAs when they have pursued the legal options open to them. However, as Hunter (2001) argues, it is

\footnotetext{
${ }^{4}$ Cf. Dwyer, (2000; 1998) on Mutual Aid Clauses in Bradford.
} 
often those tenants most in need of support (i.e. those suffering from mental or physical impairments, people with alcohol/drug dependency problems, previous victims of physical or sexual abuse etc.) who attract the majority of complaints from neighbours. Punitive legal measures that link housing rights to responsibilities look set to remain a part of policy in the near future; whether or not they tackle the underlying causes of much anti-social behaviour remains highly debatable (Hunter, 2001). Recent legislation enacted to deal with anti-social behaviour in social housing and local communities is, however, a clear example of how welfare sanctions, in this case the removal of the right to a home, are increasingly becoming part of a wider law and order agenda.

\section{Adult Education}

In December 2000 the Secretary of State for Education outlined the need for a 'radical and imaginative strategy' (Blunkett, 2000) to tackle the problem of adult illiteracy in the UK which he identified as a significant cause of social exclusion from the PLM, decent jobs and wider community networks. In setting a target to reduce the number of adults with very weak numeracy/literacy skills by $3 / 4$ million by 2004, Blunkett announced a series of pilot projects across England to begin in March 2001. Again conditionality is very much part of the UK government's thinking.

The nine localised schemes established as part of the 'Skills for Life' strategy test the effectiveness of a variety of 'carrot and stick' approaches in persuading jobseekers' allowance (JSA) claimants to learn basic skills. In Wearside appropriate individuals are referred to a full-time basic education scheme, given $£ 10$ per week extra benefit 
for attending, and $£ 100$ bonus for successful completion of the course. In contrast some claimants in north Nottinghamshire/Leeds are not so lucky. Since 17/9/01 the right to JSA of these claimants (aged 25-49) is subject to removal if they refuse, or give up, their allocated place on a basic educational skills programme. Initially benefit will be withheld for two weeks and this period will be doubled for a second 'offence' (Treolar, 2001). The government is still assessing the impacts of the scheme but it has not ruled out the possibility of national roll out even though the Social Security Advisory Committee has stated it is against sanctions in this area (SSAC, 2002).

\section{Healthcare}

The direct imposition of a principle of conditionality within the public healthcare system of the UK remains limited. ${ }^{5}$ A universal right to free healthcare continues to be a core aspect of social citizenship. However, conditionality is beginning to appear in policy. Against the backdrop of a rising number of attacks on healthcare staff (many involving patients under the influence of drink and/or drugs), the government has declared that it will support staff who (under the threat of immediate danger), make on the spot decisions and refuse treatment for violent patients (DoH 2002a). Furthermore, borrowing from the range of powers previously discussed, the Queens Medical Centre in Nottingham, has also used court injunctions and ASBOs to ban

\footnotetext{
${ }^{5}$ Rationing healthcare according to principles other than individual need, which include the denial of treatment because of an individual's habits or behaviour (e.g. drinking, smoking etc.) has, however, long been part of Nation Health Service practice in the UK. For a consideration of such debates refer to Dwyer (2000); Langan, (1998).
} 
three people from entering hospital grounds; unless they are in need of lifesaving treatment (Carvel, 2001).

An element of conditionality has been built into the improved Sure Start Maternity Grant (SSMG) (Deacon, 2002b; Dean, 2002). This grant is available to new mothers who are (or whose partners are) recipients of income support, income based JSA, working families tax credit or disabled persons tax credit. It has been increased in value from $£ 100$ to $£ 500$ in the past two years. However, payment of the grant is now conditional on a parent producing a signed certificate stating that they have received suitable advice about their new child's care from an approved healthcare professional (DoH, 2000). This may well be an example of the least punitive type of conditionality but those who do not have the relevant approval are not eligible for the grant. Statistics indicate that in the period 2001/2, 8,433 claims for SSMG were initially refused because the required certification was not provided by the applicant (DWP, 2002b).

Most recently plans to modernise the Welfare Food Scheme (which currently provides milk tokens and vitamins to mothers, babies and toddlers in 800,000 plus low income families), indicate that the government is considering a further extension of the conditional approach that it introduced for the SSMG. Under the new proposals milk tokens will be replaced by vouchers that can be exchanged for a more extensive range of healthy foods (e.g. fruit). In order to be eligible to receive the vouchers, however, mothers will have to register with certain healthcare professionals on three specified occasions before and after the birth of a child (CPAG, 2002; DoH, 2002b) 
Discussions in this section of the paper illustrate that conditionality is becoming an established and important element of social policy within the UK. The question remains, however, as to why New Labour has been able to pursue its approach to welfare reform without encountering sustained opposition. The Government's dominance in the House of Commons has been one obvious practical advantage. New Labour's persistent and persuasive repetition of the Third Way mantra 'no rights without responsibilities', and its general acceptance by all mainstream political parties in the UK, has probably been of more significance however in establishing a new consensus around social citizenship. Those citizens who refuse to accept New Labour's highly conditional approach to social welfare are widely regarded as violating the central principle at the heart of the new welfare contract between citizen and state, i.e. "that rights offered go with responsibilities owed” (Labour Party, 1997 : 1). Once this norm is broken it then becomes a relatively simple matter for the government to highlight a lack of personal responsibility on the part of the errant citizen as the root cause of an individual's lack of welfare rights. In doing so New Labour is, using Weaver’s (1986) terminology, able to 'pass the buck' (i.e. deflect the blame back for loss of social right back to the individual in question), whilst simultaneously avoiding any blame in denying some UK citizens access to public welfare.

\section{From welfare rights to conditional entitlements?}

Having outlined the details of specific legislation and initiatives in the UK it is now important to discuss the wider implications that such changes may have for contemporary notions of citizenship. Initially, this task leads us towards more 
philosophical debates concerned with our understanding of 'rights' in general and welfare rights in particular. Allied questions of the relationship between rights and responsibilities, whether rights are by their very definition unconditional, and where this leaves the idea of social/welfare rights also need to be considered. Following a brief outline of these deliberations, this section of the paper moves on to examine whether or not it is reasonable for governments (such as the New Labour administration in the UK), to rewrite the welfare contract between the individual and the state as part of the ongoing process of welfare reform. This is facilitated by a consideration of White’s (2000) defence of 'welfare contractualism' and Goodin's (2000) condemnation of such approaches.

\section{Citizenship and welfare: the demise of social rights?}

Ever since Marshall’s 1949 lecture the social rights element of his theory has been the subject of contentious debate. A number of writers, most notably, but not exclusively from the ‘libertarian’ Right of the political spectrum (e.g. Nozick, 1995; Freidman, 1962; Hayek, 1944) have effectively denied the validity of the social rights element. The standard distinction made in relation to the triumvirate of citizenship rights is between 'negative' civil and political rights on the one hand, and, 'positive' social rights on the other. This differentiation mirrors two views about the proper role of the state in relation to rights and the promotion/protection of agency among its citizenry. According to the negative view, the state's duty is to promote civil and political rights which ensure agency by protecting individuals from interference from others. The emphasis here is on is on autonomy and liberty. Supporters of 'positive' social rights on the other hand hold that in modern capitalist societies this approach is not enough; 
agency requires "some minimum material provision - that is, some sort of right to welfare” (Griffin, 2000: 29). A number of strong arguments can be mobilised to mount a philosophical defence of the notion of welfare rights and also to undermine the 'negative' position of the libertarian Right (see Griffin, 2000; Sample, 1998; Bauhn, 1997). This distinction between positive/negative understandings of rights is, however, of significance because it is often used in conjunction with another criticism of welfare rights that has become increasingly influential in recent years; namely that the existence of an extensive set of social rights has led to the formation of a welfare dependant 'underclass’ (see Mead, 1986, 1997; Murray, 1984).

Selbourne (1994) for example, concludes that a proliferation of 'dutiless rights' has led to a malaise that strikes at the heart of modern citizenship and threatens social cohesion. The way to halt this demise is to assert the primacy of a 'principle of duty' over and above the idea of rights; particularly in the social sphere. Rights to public welfare are seen here as 'generally lesser order entitlements' to privileges and benefits, which do not possess, nor should be afforded similar legal status to civil and political rights. Furthermore, he holds that "notions of egalitarian entitlement to such 'rights' which owe nothing to the individual's desert or merits," (Selbourne, 1994 :60) undermine the moral basis of the civic order. For these reasons Selbourne argues that publicly provided welfare benefits and services should not be viewed as part of the package of rights that inform a universally held status of 'citizen' but that they should be seen as potential privileges that a society may bestow on dutiful members who behave in an approved manner. In short, what are generally referred to as welfare 'rights' are nothing of the sort, they are merely highly conditional entitlements. Aspects of this interpretation of welfare rights and the respective roles of governments 
and individuals in meeting responsibilities inform New Labour's thinking on welfare reform. In making the principle of conditionality central to its approach, New Labour is moving away from Marshall’s position and endorsing the development of a welfare system in which rights to welfare are being superseded by lesser order conditional entitlements to social provisions. The extent to which this shift can be justified is explored below.

\section{Rewriting the rules or disciplining poor people?}

A defence of the principle of conditionality can be found in the work of White (2000). Access to welfare benefits is one side of the contract between the citizen and community which has as its reverse side various responsibilities that the individual citizen is obliged to meet: as a condition of eligibility for welfare benefits, the state may legitimately enforce these responsibilities, which centrally include the responsibility to work (White, 2000: 507).

The implicit assumption of this stance is that access to public welfare services is arranged around a system of conditional entitlements rather than welfare rights. Certain commentators argue that what White calls ‘welfare contractualism' violates the lack of conditionality at the core of T. H. Marshall's vision of citizenship. White refutes such arguments by stating that Marshall’s approach can be seen to be consistent with an "unconditional right of reasonable access to a given resource rather than the dominant interpretation of a right to be given the same resource unconditionally” (2000: 510). In addition he argues that Marshall himself, and the 'liberal socialist tradition' from which he emerged, would be comfortable with this approach. White also notes that Marshall did stress that responsibilities, most 
importantly the 'essential duty to work' (Marshall, 1992: 46), were part and parcel of citizenship and that they became more important in his later works (cf. Powell, 2002; Rees, 1995).

Welfare contractualism is justified by White on grounds of a 'reciprocity principle' linked to a wider understanding of distributive justice. Arguing that people are essentially 'Homo reciprocans' (i.e. co-operative beings willing to accept that it is legitimate that they be asked to make certain contributions, provided others do likewise), he also believes that welfare contractualism can be defended on the grounds that it prevents freeloaders from exploiting fellow citizens. Having made the case for welfare contractualism he then goes on to state that it is only reasonable to enforce such an approach if the society that implements it meets the following five conditions. First, the guarantee of a reasonable minimum standard of living for those who cooperate with conditional welfare schemes. Second, the provision of real opportunities, so those involved participate in a productive manner that improves the quality of life for both the individual concerned and the wider community. Third, a recognition that other forms of contribution beyond paid work (e.g. informal care work) are valid. Forth, the "universal enforcement of the minimum standard of productive participation” (White, 2000 :516). Fifth, a society must ensure that a reasonable level of equal opportunity exists for all its members.

Taking each of these conditions in turn it is possible to judge the extent to which New Labour's welfare reforms could be seen as reasonable. An element of New Labour's approach has been to improve certain benefits - e.g. child benefit, children’s allowances for those income support/income related JSA - (rf. Lister, 2001) and also 
to introduce a system of tax credits 'to make work pay'. A minimum income guarantee of $£ 179$ per week and help with child care cost for lone parents working 16 hours plus per week are also part of the Job Centre plus initiative (Blair, 2002). However, whether or not the 'enhanced' benefits offered to participants offer a reasonable standard of living is more contentious.

Assessing White's second condition concerning the need to provide real opportunities that enhance both the individual and wider society is also complicated. The 1.25 million people helped back into work since the New Deals began (Blair, 2002) are not to be dismissed lightly, but other evidence is less positive. Certain commentators have suggested that the New Deals may not be as successful as they at first appear and make strong arguments that industry and capital rather than unemployed people/lone parents are the real beneficiaries of the New Deals (Grover and Stewart, 2000; Gray, 2001; Prideaux, 2001). Peck (2001) also notes that job entry rates for the New Deal to March 2000 were modest, with overall only a third of participants leaving to enter paid work. He also argues that many of those who leave the New Deal become trapped in 'contingent employment' i.e. they continually move from one short term, low paid, insecure job to another.

The UK government's own research also indicates some strong reservations about the effectiveness of its chosen approach. Only $27 \%$ of companies participating in the ‘One’ scheme recruited lone parents to their workforce with even less (20\%) taking on the long-term unemployed. People with mental or physical impairments fared 
considerably worse ${ }^{6}$ (DSS, 2001). More recently the Adult Learning Inspectorate (a government agency) issued a damning appraisal of the New Deal for Young People. The recruitment figures noted for this scheme for the four years up to 2001 appear positive $^{7}$ but the report highlights some serious shortcomings. Sixty percent of the training for young adults provided by either the government or companies involved is condemned as inadequate. Similarly, although full-time education and training was the most popular option with recruits (40\% of $18-24$ year olds) only $26 \%$ of those participating got a job and 31\% a qualification (ALI, 2002). The aim is for all trainees to achieve both by the end of their one year course.

A number of studies have noted the potential positive effects of policies that encourage lone parents into the paid labour market but simultaneously they have emphasised that the provision of quality support and education/training schemes and help with childcare are vitally important (Heron et al, 2002; Bradshaw, 1996). The government appears to endorse these findings and, as previously noted, sets out less stringent requirements for the receipt of benefits by lone parents. However, in making it clear that in future lone parents will be expected to enter the PLM the government is implying that the contribution that they make as informal carers outside the PLM is an inadequate basis on which to make a claim for public support (Gray, 2001; Levitas, 1998). It would appear that the third condition required by White for the legitimate

\footnotetext{
$68 \%$ of participating employers recruited people with physical impairments, 5\% with mental impairments (DSS, 2001)

${ }^{7}$ Of the four options available; 112,700 young people went into full-time education/training 52,500 into government subsidised employment - 60\% of whom went onto unsubsidised employment, 60,000 to voluntary sector and 56,000 joined the environment task force (ALI, 2002).
} 
application of a reciprocity principle, the recognition of forms of contribution outside the PLM, remains unsatisfied.

White's fourth condition the 'universal enforcement of the minimum standard of productive participation' echoes Giddens (1998) declaration that the new rights/responsibilities rule must be evenly and universally applied. Although such even handed thinking is commendable it fails to reflect reality (Goodin, 2000). In relation to the social element of citizenship it is largely the rights of poor people that are being reduced whilst simultaneously the attendant responsibilities required to access those rights are being increased (Dwyer, 2002, 2000, 1998:). As for the final contingency required i.e. a reasonable level of equality of opportunity for all members of British society, the government by its own admission recognises the limits of contemporary meritocracy in the UK. The Treasury, as Deacon (2002b) notes, believes that the opportunities available to citizens "are determined by who their parents were rather than their own talents and efforts” (HM Treasury, 1999: 31).

Noting a ‘draconian reform’ of work based social security payments across the OECD Goodin (2000) is keen to challenge the legitimacy of the imposition of conditionality by questioning the principles used to support recent reforms. Dismissing arguments that people implicitly consent to a rewriting of the welfare contract that exists between the individual citizen and the state, Goodin notes that this argument falls down on two levels. At the client/caseworker level he argues that such contracts are one sided. In effect the coercion/compulsion of the user is couched as consent. Consent implies a notion of choice and given that people have real needs for their benefits the element of choice is missing from the process. At the 'macro level' it is often stated that there is a 
wider communal agreement to the idea of a new highly conditional welfare settlement. However, it is politicians, not users, who are, "by their own admission, tearing up the old social contract...demanding more of the poor...[and] unilaterally altering the terms of the contract” (Goodin, 2000 :5). The reciprocity principle is also dismissed as seriously flawed. As Goodin notes the obligations that we have to each other should be more properly regarded as mutual rather than reciprocal.

We each have obligations to the other, but those obligations are independent of one another. Consequently, my obligations toward you remain in force, even after you have defaulted on yours to me (Goodin, 2000 :8)

Why, he asks, if we accept a duty of care for criminals who have committed terrible crimes, should we be allowed to renege on our duty to support certain fellow citizens who are not in the PLM, or who behave in what is deemed to be an irresponsible manner? White's (2000) assertion, that in certain circumstances, conditionality can be justified on paternalistic grounds is similarly dismissed. Goodin believes that unemployment is largely due to wider structural factors rather than individual failings that limit people's ability to engage with the PLM. 'Weak' paternalism misses the point. It implies a sort of addiction to idleness that is generally not there. 'Strong' paternalism - based on the idea that work is good for you so we're going to make you do it! - is undermined by the fact that we don't compel the idle rich to work with the same vigour that is reserved for poor people.

In the UK the New Labour government is distancing itself from the notion of welfare rights and increasingly embracing, in both principle and practice, the idea that public welfare provisions are conditional entitlements. This further diminishes the limited 
equality that the citizenship of the British PWWS promised. This diminution of welfare rights will have the greatest negative effect on those most in need.

\section{Conclusions}

A principle of conditionality already underpins New Labour's employment policy. It is also an increasingly important tool in the management of social housing tenants. Emerging policies and debate centred on applying sanctions to the housing and child benefits of irresponsible parents serves to illustrate several important points. First, the ideological distance that New Labour has travelled in a relatively short time. Less than a decade ago the Labour Party was opposed to workfare type unemployment schemes. In 2002 a New Labour Prime Minister was seriously considering the removal of child benefit in certain (extreme) circumstances. If Blair's rhetoric ever becomes reality and the removal/reduction of child benefit rights from parents of persistent truants becomes policy it needs to be considered that whilst, theoretically, the regulations will be universal in application, their punitive effect will be selectively felt. Because child benefit remains, for good reasons, a benefit routinely paid to mothers it will largely be women (and children) rather than men who are denied welfare. Similarly, because removing $£ 15.50$ per week from an unemployed lone mother whose child persistently truants is qualitatively different from applying the same sanction to a middle class dual earning couple, it will be poor women and children who will suffer the most.

Second, conditionality lays bare some of an inherent contradiction at the heart of the New Labour's welfare project. It is a stated aim of the present administration to 
challenge welfare dependency, but as Grover and Stewart (2000) note, only certain types of dependency are deemed to be problematic.

Obviously, for Labour's true believers having a job which only exists because of some scheme of subsidy, and using subsidised nursery places for one's children, is not part of benefit dependency, whereas looking after one's own children at home on benefit is dependency (:248).

Third, emergent policies and debates indicate a strengthening link between the social welfare and criminal justice systems. Regulation and social control has long been a central aspect of state welfare (Bauman, 1998). New Labour evidently sees it as entirely appropriate to use welfare sanctions as an adjunct of the legal system in order to enforce responsible behaviour.

Recognising our wider responsibilities and respecting the rights of others to live in peace are central to any notion of citizenship. Governments, however, are wrong to place a principle of conditionality at the heart of their welfare state reforms. As Douglas Hurd (British Conservative Home Secretary 1985-1989), rather ironically given the position he was defending pointed out, “compulsion by the state implies not the fulfilment, but the absence or failure of personal responsibility” (Hurd, 1988: 16).

The wider shift towards 'active/Third Way' welfare states is an attempt by Western governments to renegotiate the welfare deal between citizen and the state. Rights are conditional on the acceptance of attendant individual responsibilities. This represents a significant qualitative shift away from the public welfare envisaged in the PWWS, built around notions of need and entitlement. On one level the changes outlined in the paper may be seen as incremental (hence the title of 'creeping conditionality'); but 
such changes are significant. They illustrate a more substantial shift in the principles that underpin state welfare provision (Cox, 1998; Taylor-Gooby, 2002).

\section{Bibliography}

ALI (2002) Qualifications 2002/26. Annual Report of the Chief Inspector, Coventry: Adult Learning Inspectorate.

Bauhn, Per. (1997) “The justification of welfare rights,” in Peter Koslowski and Andreas Follesdal, [eds.] (1997) Ethics in public service. Berlin: Springer Verlag :277- 288

Bauman, Zygmund (1998) Work Consumerism and the New Poor. Buckingham: Open University Press.

Béland, Daniel; Vergniolle de Chantel, François and Waddan, Alex (2001) 'Third way social policy: Clinton’s legacy?’ Policy and Politics 30(1): 19-30.

Blair, Tony (1998) The Third Way: New Politics for a New century. London: The Fabian Society.

Blair, Tony (2002) Speech on Welfare Reform. London, 11/6/02 available at http://www.number-10.gov.uk/output/Page5292.asp (6/13/03). 
Blunkett, David. (2000) Skills for Life. The National Strategy for Improving Adult Literacy and Numeracy Skills. London: Department for Education and Employment.

Bivand, Paul (2001) 'New Deal sanctions.' Working Brief 121, London: Centre for Social and Economic Inclusion.

Bradshaw, Jonathan (1996) Lone mothers and work, Findings, York: Joseph Rowntree Foundation.

Carvel, John (2001) 'Violent patients may be refused care.’ The Guardian, 28/12/01:

9.

Card, Pauline (2001) 'Managing anti-social behaviour - inclusion or exclusion?' in David Cowan and Alex Marsh, [eds.] (2001) Two Steps Forward: Housing Policy into the Millennium, Bristol: Policy Press :201- 219.

Cox, Robert Henry (1998) 'The consequences of welfare reform: How conceptions of social rights are changing.' Journal of Social Policy 27(1): 1-16.

CPAG (2002) ‘Government rethink on sanctions?’ Campaigns Newsletter. London: Child Poverty Action Group, 24:1.

Deacon, Alan (1994) 'Justifying workfare; The historical context of the workfare debates,' in Michael White [Ed.] (1994) Unemployment and Public Policy in a Changing Labour Market. London: Public Services Institute :53-63. 
Deacon, Alan (2002a) Perspectives on Welfare: Ideas, Ideologies and Policy Debates, Buckingham: Open University Press.

Deacon, Alan (2002b) 'Echoes of Sir Keith? New Labour and the cycle of disadvantage.' Benefits. 10(3): 179-185.

Dean, Hartley (2002) Welfare Rights and Social Policy. Harlow: Pearson Education.

DoH (2002a) Withholding Treatment from Violent and Abusive Patients: Resource

Guide. London: Department of Health available at

http://www.nhs.uk/zerotolerance/wh_treatment/index.htm (8/20/02).

DoH (2002b) Healthy Start: Proposals for Reform of the welfare Food Scheme.

London: Department of Health.

DoH (2000) 'Introduction of the Sure Start maternity grant.' Letter from the Chief Medical Officer and the Chief Nursing Officer. London: Department of Health.

Driver, Stephen and Martell, Luke (1998) New Labour: Politics after Thatcherism. Cambridge: Polity Press.

DSS (2001) 'Recruiting benefit claimants: a survey of employers in ONE pilot areas.' Research Report no. 139, London: Department of Social Security. 
DTLR (2002) Tackling Anti-social Tenants: A Consultation Paper, London:

Department of Transport, Local Government and the Regions.

DWP (2004) 'Report on consultation on sanctions against anti-social behaviour published', Press Release,27 January 2004. London: Department for Work and Pensions. Available at http://www.dwp.gov.uk/mediacentre/pressreleases/2004/jan/fram2701-sanction.asp $(01 / 29 / 2004)$

DWP (2002a) Jobseeker's Allowance. Quarterly Statistical Enquiry May 2002.

London: Department for Work and Pensions.

DWP (2002b) ‘Sure Start Maternity Grants. Request for information.’ Report to enquiry from Peter Dwyer. London: Information and Analysis Directorate, London: Department of Work and Pensions.

Dwyer, Peter (1998) 'Conditional citizens? Welfare rights and responsibilities in the late 1990’s.' Critical Social Policy 18(4): 519-543.

Dwyer, Peter (2000) Welfare Rights and Responsibilities: Contesting Social Citizenship. Bristol: Policy Press.

Dwyer, Peter (2002) 'Making sense of social citizenship: some user views on welfare rights and responsibilities.' Critical Social Policy 22 (2): 273-299. 
Etzioni, Amitai (1997) The New Golden Rule: Community and Morality in a Democratic Society. London: Profile Books.

Etzioni, Amitai (2000) The Third Way to a Good Society. London: Demos.

Field, Frank (2002) 'First take their benefits, then their children.’ The Sunday Telegraph, 18/5/02: 20.

Finch, Naomi (2002) 'New Labour’s value laden social policy.’ Paper to the Social Policy Association Conference. University of Teeside, July 2002.

Flint, John (2002) 'Return of the governors: citizenship and the governance of neighbourhood disorder in the UK.' Citizenship Studies 6(3): 245-264.

Freidman, Milton (1962) Capitalism and Freedom. Chicago: University of Chicago Press.

Giddens, Anthony (1994) Beyond Left and Right: The Future of Radical Politics, Cambridge: Polity Press.

Giddens, Anthony (1998) The Third Way: The Renewal of Social Democracy. Cambridge: Polity Press.

Goodin, Robert Edward (2000) 'Principles of welfare reform: the OECD experience.' Paper to the Conference on Welfare Reform. Melbourne Institute: November 2000. 
Goodin, Robert Edward (2002) 'Structures of mutual obligation.’ Journal of Social Policy 31(4): 579-596.

Gray, Anne (2001) 'Making work pay - devising the best strategy for lone parents in Britain.’ Journal of Social Policy 30(2): 189-207.

Griffin, James (2000) 'Welfare rights.' The Journal of Ethics, 4: 27-43.

Grover, Chis and Stewart, John (2000) Modernising social security? Labour and it's welfare-to-work strategy.’ Social Policy and Administration, (34)3: 235-252.

Hansard (2002) Question in House of Lords from Earl Russell to the Parliamentary Under-Secretary of State, Department for Work and Pensions on Benefit Sanctions, Hansard $8^{\text {th }}$ May 2002 column WA181, available at http://www.parliament.thestationery-0.../ldhansrd/pdvn/1ds02/text/20508w03.htm (8/20/02).

Hayek, Friedrich A. (1944) The Road to Serfdom. London: Routledge: Keegan and Paul.

Heron, Emma; Bennett, Cinnamon; Pearson, Sarah; Steill, Bernadette and Yeandle, Sue (2002) 'Moving on up? Motivations, aspirations and barriers to paid employment for lone parents.' Paper to the Social Policy Association Conference. University of Teeside, July 2002. 
Heron, Emma and Dwyer, Peter (1999) 'Doing the right thing:’ Labour’s attempt to forge a new welfare deal between the individual and the state.' Social Policy and Administration 33(1): 91-104.

HM Treasury (1999) Tackling Poverty and Extending Opportunity: The Modernisation of Britain’s Tax and Benefit System. London: Her Majesty’s Stationary Office.

Home Office (2003a) Anti-Social Behaviour Orders: Statistics. http://www.crimereduction.gov.uk/asbos2.htm (11/12/03).

Home Office (2003b) Respect and Responsibility-Taking a Stand Against Anti-Social Behaviour. Cm 5778. London: The Stationary Office.

Hunter, Chris (2001) 'Anti-social behaviour and housing can-law be the answer?’ in David Cowan and Alex Marsh [eds.] (2001) op cit. :221- 237.

Hurd, Douglas (1988) 'Citizenship in Tory democracy.' The New Statesman, 4/29/88: 16.

King, Desmond (1999) In the Name of Liberalism: Illiberal Social Policy in the United States and Britain. Oxford: Oxford University Press.

Labour Party (1997 Leading Britain into the future. London: Labour Party. 
Langan, Mary (1998) 'Rationing healthcare’, in Langan, M. [ed.] (1998) Welfare, needs, rights and risks. London: Routledge/Open University Press: 35-80.

Levtias, Ruth (1998) The Inclusive Society? Social Exclusion and New Labour.

Basingstoke: Macmillan.

Lister, Ruth (1998) 'From equality to social exclusion: New Labour and the welfare state.' Critical Social Policy 18(2): 215-225.

Lister, Ruth (2001) 'New Labour a study in ambiguity from a position of ambivalence.' Critical Social Policy 21(4): 425-447.

Lǿdemel, Ivar and Trickey, Heather (2000) 'An Offer You Can’t Refuse.' Workfare in International Perspective. Bristol: Policy Press.

Marshall, Thomas Herbert (1992) 'Citizenship and social class’, in Marshall, T. H. and Bottomore, Tom (1992) Citizenship and Social Class. London: Pluto Press, : 339.

Mead, Lawrence M. (1986) Beyond Entitlement. New York: Free Press.

Mead, Lawrence M. (1997) ‘Citizenship and social policy: T. H. Marshall and poverty.' Social Philosophy and Social Policy. 14(2): 197-230.

Murray, Charles (1984) Loosing Ground. New York: Basic Books. 
Nixon, John, Hunter, Chris and Shayer, Sarah (1999) The Use of Legal Remedies by Social Landlords to Deal with Neighbour Nuisance. Sheffield: Centre for Regional Economic and Social Research Paper no. H8, Sheffield Hallam University.

Nozick, Robert (1995) 'Distributive justice’ in Shlomo Avineri, and Avner de-Shalit, [eds.] Communitarianism and Individualism. Oxford: Oxford University Press, :137150

O’Connor, James (1998) 'US Social welfare policy: the Reagan record and legacy.' Journal of Social Policy 27(1): 37-61.

Pierson, Paul. (1996) 'The new politics of the welfare state.' World Politics 49: 143179.

Pierson, Paul (2001) [ed.] The New Politics of the Welfare State. Oxford: Oxford University Press.

Peck, Jamie (2001) 'Job Alert! Shifts, spins and statistics in welfare to work policy.' Benefits, 30: 11-15.

Powell, Martin [ed.] (1999) New Labour New Welfare State? The Third Way in British Social Policy. Bristol: The Policy Press. 
Powell, Martin (2002) 'The hidden history of social citizenship.' Citizenship Studies. 6(3): 229-244.

Prideaux, Simon (2001) 'New Labour, old functionalism? The underlying contradictions of welfare reform in the UK and the US.' Social Policy and Administration 35(1): 85-115.

Rees. Anthony M. (1995) ‘The other T. H. Marshall.’ Journal of Social Policy 24(4) 341-362.

Sample, Ruth (1998) 'Libertarian rights and welfare rights.' Social Theory and Practice 24(3): 393-418.

Selbourne, David (1994) The Principle of Duty, London: Sinclair Stevenson.

Smith, Robert; Stirling, Tamsin; Papps, Pauline; Evans, Angela and Rowlands, Robert (2001) Allocations and exclusions: the impact of new approaches to allocating social housing. London: Shelter.

SSAC (2002) Social Security Advisory Committee Fifteenth Report April 2001-March 2002. London: Her Majesty’s Stationary Office.

Taylor-Gooby, Peter (2002) 'The silver age of the welfare state: perspectives on resilience.' Journal of Social Policy, 31(4): 596-622. 
Treolar, Paul (2001) ‘Compulsion creeps up’ Welfare Rights Bulletin, 164 October, London, Child Poverty Action Group available at http://www.cpag.org.uk/cro/wrb/wrb164/compulsion.htm. (11/11/01).

Van Oorschot, Wim (2000) 'Who should get what and why? On deservingness and the conditionality of solidarity among the public.' Policy and Politics 28(1): 33-48.

Walters, William (1997) 'The active society: new designs for social policy.' Policy and Politics 25(3): 221-234.

Weaver, R. Kent (1986) ‘The politics of blame avoidance’’ Journal of Public Policy, 6(4): 371-398.

Wetherley, Paul (2001) 'The reform of welfare and the way we live now: a critique of Giddens and the Third Way.' Contemporary Politics, (7)2: 149-170.

White, Stuart (2000) 'Review article: social rights and social contract - political theory and the new welfare politics.' British Journal of Political Science 30: 507-532.

Williams, Fiona (1999) ‘Good enough principles for welfare.’ Journal of Social Policy 28(4): 667-688. 